Relations industrielles

Industrial Relations

The Prospects for Greater Enforcement of Teen Employment

Laws in Alberta, Canada. "Politically, how do you make it

relevant? [...] Kill more young people!”

Les perspectives d'un renforcement des lois relatives au travail

des jeunes en Alberta, Canada. « Comment rendre cela pertinent politiquement? [...] en tuant davantage de jeunes! "

Las perspectivas de una mejor aplicación de la ley sobre

elempleo de adolescentes en Alberta, Canadá. 'Políticamente, cómo hacer esto sea adecuado? ...Matar gente tan joven'.

\title{
Bob Barnetson
}

Volume 70, numéro 3, été 2015

URI : https://id.erudit.org/iderudit/1033410ar

DOI : https://doi.org/10.7202/1033410ar

Aller au sommaire du numéro

Éditeur(s)

Département des relations industrielles de l’Université Lava

ISSN

0034-379X (imprimé)

1703-8138 (numérique)

Découvrir la revue

Citer cet article

Barnetson, B. (2015). The Prospects for Greater Enforcement of Teen Employment Laws in Alberta, Canada. "Politically, how do you make it relevant? [...] Kill more young people!”. Relations industrielles / Industrial Relations, 70(3), 558-583. https://doi.org/10.7202/1033410ar

\section{Résumé de l'article}

La présente étude a recours à une analyse de type Delphi afin d'identifier les principales barrières au développement de pressions soutenues et sérieuses sur le gouvernement albertain pour qu'il améliore ses lois relatives à l'emploi des jeunes. Actuellement, outre des lois générales en matière d'emploi (par exemple, sur les salaires, la santé et sécurité au travail) — lois qui semblent peu appliquées - l'Alberta apparaît également peu encline à renforcer ses lois déterminant le nombre d'heures durant lesquels les jeunes peuvent travailler, tout comme les tâches qu'ils peuvent accomplir. Le résultat en est un de " vol " salarial, d'accidents de travail et de formes illégales d'emploi pour les jeunes. Les sept participants au panel Delphi - des représentants provenant du monde académique, du milieu syndical et d'agences à but non lucratif, ayant tous un intérêt pour les questions d'emploi des jeunes - identifient la relation serrée entre milieux d'affaires et gouvernement comme étant la limite principale aux possibilités politiques de changements. Les réformateurs font également face à un ensemble de préjugés qui minimisent les préoccupations envers le travail des jeunes, préjugés s’appuyant sur l'idée qu'un environnement illégal ou dangereux au travail constitue une sorte de passage initiatique à l'âge adulte. Ensemble, ces barrières limitent significativement les possibilités de faire pression sur l'État afin qu'il légifère pour améliorer la situation.

Les participants ont également noté l'absence de structures de mobilisation auxquelles pourraient avoir accès les jeunes travailleurs et leurs alliés. Le mouvement syndical albertain a, de plus, connu un succès limité dans ses tentatives d'organisation du secteur des services (là où la majorité des jeunes travaillent). Certains participants pensent que la lutte contre les abus sexuels généralisés à l'égard des jeunes travailleuses permettrait d'accéder aux réseaux et à des ressources existantes dans le mouvement féministe et dans les organisations syndicales. D'autres, par contre, sont d'avis que mettre l'emphase sur la lutte contre les abus sexuels ne ferait que cibler les comportements déviants d'employeurs individuels et obscurcirait le fait que la volonté de ne pas renforcer les lois repose sur des intérêts de classe.

La plupart des participants proposent de souligner le caractère socialement inapproprié des blessures sérieuses, voire même de décès, de jeunes travailleurs, ce qui pourrait constituer un moyen important d'ébranler les barrières actuelles à l'égard du renforcement de ces lois. De telles occasions sont plutôt rares et il peut être difficile de capitaliser sur celles-ci. Hors de tout doute, la recherche au Canada sur les professions à haut risque d'accidents mortels démontre que les tragédies (par exemple, le désastre de la Mine Westray) ont peu d'effet significatif sur les efforts des États à renforcer l'application des lois en la matière. Entre-temps, les partisans de réformes, comme les membres d'organisations syndicales et de groupes communautaires, peuvent oeuvrer à modifier la perception conventionnelle à l'égard de l'emploi des jeunes, tout en supportant les efforts provenant des milieux artistiques et de l'éducation qui se préoccupent des conditions de travail des jeunes. Leur analyse pourrait également inclure l'identification des risques et des conséquences de ne pas appliquer les lois régulant le travail des jeunes (comme les blessures et le « vol " salarial), de même que l'élaboration des raisons qui militent en faveur d'un renforcement par l'État des droits des jeunes en milieu de travail.
Tous droits réservés (C Département des relations industrielles de l'Université Laval, 2015
Ce document est protégé par la loi sur le droit d'auteur. L’utilisation des services d'Érudit (y compris la reproduction) est assujettie à sa politique d'utilisation que vous pouvez consulter en ligne.

https://apropos.erudit.org/fr/usagers/politique-dutilisation/ 


\section{The Prospects for Greater Enforcement of Teen Employment Laws in Alberta, Canada. "Politically, how do you make it relevant? [...] Kill more young people!"}

\section{Bob Barnetson}

This Delphi analysis uses social movement theory to identify significant barriers to the development of sustained and meaningful pressure on the government of the Canadian province of Alberta to enforce its laws regulating teen employment. In Alberta, the law specifies the occupations in which teens may be employed, the tasks they may perform and the times they may work. Teens are also subject to normal workplace rules around wage payments, deductions and occupational health and safety. Seven panelists-including academics, trade unionists and staff members in notfor-profit agencies with an interest in employment matters-identified that a tight business-government relationship limits the political opportunities available to insurgents seeking change. Insurgents must also grapple with a framing of violations as a rite of passage and an educational process which minimizes concerns about violations. The absence of a mobilizing structure reflects the inability and/or unwillingness of organized labour to represent workers in the service sector wherein teen employment is concentrated and poses a serious barrier to change. Panelists identified highlighting the socially unacceptable nature of fatalities and other serious work-related injuries to teens as the most likely pathway to destabilizing the existing framing and power structure around teen employment in Alberta.

KEYWORDS: Teen, employment, injury, social movement theory, Delphi.

\section{Introduction}

The employment of teenagers in the Canadian province of Alberta is widespread and frequently illegal and injurious. A full 43.7\% of adolescents (aged 12-14) surveyed indicated that they had been employed during the previous year, with $21 \%$ working in illegal occupations and $50 \%$ working in occupations wherein the legality of their employment was unclear (Barnetson, 2010, 2013a). Only 23.9\% 
of employed Alberta adolescents had had workplace hazards disclosed to them and only $27 \%$ reported receiving health and safety training. Among employed teens, $47.9 \%$ reported experiencing a workplace injury in the previous year. The percentages of young persons (aged 15-17) who were employed, trained and injured were slightly higher (Barnetson 2013a). Despite this situation, the enforcement of statutory employment laws affecting teens is deteriorating, with teen-specific workplace inspections being discontinued (Clark, 2013) while the province explores the possibility of further loosening the rules around employment (Alberta, 2014).

This study uses social movement theory to frame a Delphi analysis of the potential for the development of sustained and meaningful pressure on the provincial government to enhance the enforcement of employment laws. Our analysis reveals a series of interlocking barriers to greater enforcement, including a close relationship between government and business, the framing of illegal and injurious teen employment as being non-problematic, and the absence of a mobilizing structure for potential insurgents. The panelists identified two (potentially complementary) strategies: 1 - direct action by insurgents and advocates to destabilize the existing power structure supporting non-enforcement; and 2- framing violations as highly problematic by focusing on socially unacceptable nature of the death or serious injury of teenage workers.

\section{Child Labour in Developed Countries}

Teenagers are often employed in developed countries. The proportion of 15to 19-year-olds reporting employment during any given year has been measured at $45.6 \%$ in Australia, $32.9 \%$ in Canada, $52.2 \%$ in the United Kingdom and $34.8 \%$ the United States (Dorman, 2001). Governments generally do not track the employment of those under 15. In Canada, Breslin et al. (2008) reported adolescent employment in British Columbia at $41.5 \%$ in 2005 and in Ontario at $52.9 \%$ in 2003. Barnetson (2013a) reported adolescent employment in Alberta at $43.7 \%$ in 2012. Similar levels are reported in the United States (Zierold and Anderson, 2006a; Zierold et al., 2004) and New Zealand (CARITAS, 2003).

Employment is said to provide teens with valuable developmental experience (Runyan et al., 2009; Staff et al., 2009). Critics of teen employment often cite its association with school leaving and declining academic performance, although longitudinal US research suggests a complex relationship (Mortimer, 2003). There is good evidence that employment exposes teens to injurious and otherwise undesirable work situations (Tucker et al., 2014; Lewko et al., 2010; Anderson et al., 2008; McCall et al., 2007; Breslin et al., 2007a; Levine, 2003; Evensen et al., 2000; Pickett et al., 1999; Dufort et al., 1997; Parker et al., 1994a; Brooks et al.,1993). 
Reliable injury statistics for teen workers are elusive. In Canada, Raykov and Taylor (2013) found that 31\% of employed young persons reported injuries that were serious enough to limit normal activities on the day following the injury. $A$ convenience sample of Alberta teens found that $49.7 \%$ of employed adolescents and $59.0 \%$ of employed young persons had experienced at least one work-related injury in the previous year, with most reporting multiple injuries (Barnetson, 2013a). Breslin et al. (2008) reported that 6.0\% and 3.5\% of adolescent workers in Ontario and British Columbia, respectively, reported injuries that were serious enough to require medical treatment. In the US, between 15 and $26 \%$ of adolescent workers (i.e., aged 12-14) reported permanent impairments related to employment (Parker et al., 1994a, 1994b). The risk of workplace injury among 14- to 17-year olds in the US is reported at 54\% (Dunn et al., 1998).

Teenagers frequently hold precarious jobs, "characterized by limited social benefits and statutory entitlements, job insecurity, low wages and high risks of ill health" (Vosko, 2006: 4). Employment precarity is associated with a greater risk of work-related injury or illness and a lower propensity to report such injuries (Probst et al., 2013; Lewchuk et al., 2011; Lewchuk et al., 2006; Quinlan et al., 2001; Quinlan and Mayhew, 1999; Quinlan, 1999). Occupation is highly correlated with injury among teens, although there are also independent jurisdictional and sub-jurisdictional (Breslin et al., 2006, 2007b) as well as gender (Cohen, 2013; Breslin et al., 2007c) differences. There is evidence suggesting that the injuries suffered by teen workers are less serious than those suffered by adult workers (Breslin et al., 2003, but see Runyan et al., 2012); however, the long-term impact of their more serious injuries is significant (Koehoorn et al., 2008).

It is often argued that workplace injuries are the result of worker ignorance, and training is thus prescribed (Barnetson, 2013b; Power and Baqee, 2010). There is weak but conflicting evidence that education reduces workplace injuries (D'Arcy et al., 2011; Tullar et al., 2010; Waehrer and Miller, 2009; Bell and Grushecky, 2006; Burke et al., 2005; Dong et al., 2004; Kinn et al., 2000). Large numbers of new and young workers do not receive health and safety training (Smith and Mustard, 2007; Breslin et al., 2003) and the training they do receive focuses on imparting knowledge rather than developing self-advocacy skills (Chin et al., 2010; Shearn, 2006; Blair et al., 2004). Laberge et al. (2014) note that OHS training for young workers often ignores how the context in which the OHS instruction takes place differs from the context in which work occurs, including the conflict between work demands and safety rules.

All Canadian jurisdictions limit employment type, duties, duration and location for minors. The employment of "children" under the age of 12 is normally prohibited. As in other provinces, Alberta's Employment Standard Code restricts adolescents (12-14) to light work during non-school hours while young persons 
(15-17) face fewer restrictions. Violations of child labour laws appear commonplace in developing countries (Barnetson, 2013a; Dal Santo and Bowling, 2009; Rauscher et al., 2008; Kruse and Mahony, 2000). The enforcement of Canadian workplace laws is largely complaint-driven and reveals only a minority of violations (Thomas, 2009; Arthurs, 2006; Ontario, 2004). Workers may choose not to complain because of ignorance, lack of self-efficacy, and/or belief that remedy is unlikely (Weil and Pyles, 2005), thereby creating a culture of noncompliance, wherein workers complain less even as violations increase (Weil, 2012). Injury-prevention regulations are ineffective without enforcement (Tompa et al., 2007). Further, complaint-driven enforcement may be inappropriate for minors: they are less likely than adults to know and assert their rights and they face the power differential associated with adult-child relationships (Tucker and Turner, 2013; Bernstein et al., 2006). While parents may intend to intervene in workplace issues, it is unclear whether they do so (Usher et al., 2014; Runyan et al., 2011; Barnetson, 2010).

There is no regular collection of employment data on Alberta teens under the age of 15 and data on employment of those over 15 tends to be aggregated into a 15- to 24-year-old category. Observationally, teen employment in Alberta is concentrated in the service sector (i.e., restaurants and retail). There is no regular statistical reporting of violations of Alberta's Employment Standards Code or Occupational Health and Safety Act by the government. Injury reports in Alberta are based on data regarding workers' compensation claims and systematically under-report injuries (Barnetson, 2012). Although academic research indicates that the employment of Alberta teens is frequently illegal and injurious (Barnetson 2010, 2013a), Alberta loosened the rules around the employment of adolescents in 2005 (Shultz and Taylor, 2006). When faced with evidence of employment illegality (Barnetson, 2009a, 2010), legislators mocked the research rather than examining it (Alberta, 2011a) and subsequently argued in favour of further loosening the rules (Alberta, 2014). Government workplace safety education aimed at teens has adopted a "blame the victim" approach with little emphasis on developing self-advocacy skills (Barnetson and Foster, 2012; Chin et al. , 2010) and youth-specific enforcement of employment laws has quietly been downgraded (Clark, 2013). Worker advocates privately note that the government faces little sustained or meaningful pressure regarding the (non-)enforcement of teen employment laws.

\section{Social Movement Theory}

Social movement theory explains the emergence and development of social movements and thus provides a useful analytical framework for identifying opportunities and barriers related to the development of sustained pressure to increase Alberta's enforcement of its teen employment laws. The three main 
factors central to modern social movement theory are political opportunities, mobilizing structures and framing processes (McAdam et al., 1996). Political opportunities are openings for insurgents to advance social change. These opportunities are often influenced by the broader political and institutional structure, which enable and constrain collective action. Mobilizing structures are the informal and/or formal collective vehicles and resources that allow individuals to take advantage of political opportunities. Framing processes allow individuals to develop a sense of grievance and see their situation as amenable to change through collective action.

Political opportunities, mobilizing structures and framing processes are interrelated. While political opportunities can spontaneously emerge, they can only be seized if there is an adequate degree of organization among individuals and agreement to take action. Political opportunities can trigger framing processes by, for example, revealing the illegitimacy of an existing situation or structure. Moreover, the access that individuals have to mobilizing structures (and the kinds of structures they can access) affects the likelihood and relative impact of the framing process. Without some means by which a (ideally homogenous) group can come together (ideally regularly and intensely), it is unlikely that meaningful framing activity will occur and, thus, the driver of collective action would be absent. While individual grievances may remain, the cause is likely to be internalized in conditions of social isolation.

The literature suggests that four dimensions of the political opportunity structure warrant scrutiny:

1. The degree of openness of the political system to the demands of insurgents.

2. The (in)stability of the economic and political relationships among powerful actors in the policy community.

3. The presence or absence of powerful allies for insurgents.

4. The state's ability and willingness to repress dissent (McAdam, 1996; Jenkins and Klandermas, 1995; Kriesi, 1995).

The interaction of these variables is posited to at least partially explain the timing and outcome of social movement activity, as well as the form of the movement. Relatively unexplored in the literature is the possibility that movements can also affect the opportunity structure (Gamson and Meyer, 1996). Most workers are members of various (and overlapping) potential mobilizing structures, such as families, friendship networks, voluntary associations, work units and even government structures (McCarthy, 1996). A key question is whether potential advocates have a structure(s) available to them of sufficient strength to start a movement and, subsequently, whether they can develop a sustainable 
movement. The available mobilizing structures are fixed in the short-term and tend to influence the kinds of tactics available (and acceptable) to members of a group. They also influence how issues are framed.

Framing processes occur in specific cultural contexts, drawing on cultural stocks to determine what is right and wrong, just and unjust. Specific social movements draw on "frames available to and compatible with the skills, orientation and styles of the groups that make them up" (Zald, 1996: 267). There are four types of cultural opportunities that appear to increase the likelihood of movement activity, including

...1- the dramatization of a glaring contradiction between a highly salient cultural value and conventional social practices; 2- "suddenly imposed grievances"; 3- dramatizations of a system's vulnerability or illegitimacy; and 4- the availability of an innovation "master frame" within which subsequent challengers can map their own grievances and demands (McAdam, 1996: 25).

These (re)framing opportunities may flow from (or contribute to) events that also create political opportunities. While the initial development of a shared framing is not necessarily a conscious process, sustained movements do tend to strategically frame issues (McAdam et al., 1996). Social entrepreneurs (e.g., journalists, activists) may also engage in framing and these efforts, over time, may alter the cultural stocks available to individuals and groups. Indeed, framing outside of the movement is necessary to mobilize the broader public (Zald, 1996).

\section{Methodology}

The impetus for this study was questions by trade unionists, community development practitioners and staff members in not-for-profit agencies addressing employment issues about why triggering greater enforcement of teen employment laws was so difficult despite mounting evidence of illegal and injurious working conditions. Initial discussions suggested that a lack of sustained and meaningful pressure meant that neither politicians nor civil servants had any real reason to intensify enforcement and that employers pressured politicians to reduce enforcement.

Previous research (Barnetson, 2009b) suggested that social movement theory would provide a useful analytical framework to structure inquiry into the opportunities and barriers to developing sustained and meaningful pressure on the state around employment issues. This framework informs three research questions. While each question engages a single dimension associated with social movement emergence, each question also addresses the inter-related nature of these dimensions: 
1. What framing processes currently exist around teen employment and its regulation? How do they affect and how are they affected by the political opportunities and mobilizing structures in place?

2. What political opportunities exist (or are likely to exist) that would trigger greater state enforcement of teen employment laws? Are these opportunities contingent on any particular framing processes and/or mobilizing structures?

3. What mobilizing structures exist (or are likely to exist) that could be deployed to trigger greater state enforcement? What framing processes are necessary to create or enhance such structures?

A Delphi approach was used to generate data. The Delphi method was selected because the questions do not lend themselves to a precise analytical technique but, rather, are usefully approached through individual judgments rendered on a collective, iterative basis (Adler and Ziglio, 1996; Skulmoski et al., 2007). As per Okuli and Pawlowski (2004), an initial list of groups from which panelists should be drawn was formulated, including academics, civil servants, employers, not-for-profit practitioners, and trade unionists. The small size of Alberta's policy community precluded separate panels for each group, so at least three knowledgeable individuals in each category were approached to populate a single panel. The individuals contacted were selected based on their knowledge of the enforcement level of employment laws affecting teen employment as evidenced by their prior participation in public or private discussions. Difficulty recruiting employers and civil servants meant that a total of nine employers and four civil servants were eventually approached but none agreed to participate in the panel. Those who gave a reason for declining indicated opposition to the research question and/or fear of employment consequences. The seven panelists (six men, one woman) who agreed to participate included two academics (experts in labour relations and education respectively), two union activists (both presently researchers) and three not-for-profit staff members (one from a think tank and two with experience delivering safety education to teens). The Athabasca University Research Ethics Board approved the study.

One-hour, semi-structured individual interviews provided initial data on four questions addressing the lack of enforcement of labour laws and the prospect for better enforcement. The interviews were transcribed and analyzed by the researcher to identify themes and issues identified by the panel (e.g., relationship between state and employer groups, injuries as a rite of passage, young workers as particularly vulnerable, parents as lacking information about workplace conditions). These emergent themes were used to develop a coding system and all transcripts were hand-coded by the researcher. The resulting data was used to develop an initial Delphi document identifying major themes with exemplars and 
explanatory text. This document was blindly circulated to the panelists for feedback and revised accordingly. Some panelists provided written feedback while others provided verbal feedback (which was transcribed and merged with the written feedback).

The first round of feedback broadly validated the initial Delphi document. There was minor disagreement around the cost to teens of exiting work. Some panelists asserted that the cost of exiting a workplace was low for teens because their wages were predominantly used to generate disposable income (e.g., to pay for entertainment and other discretionary items). Other panelists asserted that some teens worked in order to provide necessities (e.g., food, shelter) for their families and, for these teens, the cost of exiting work would be high. There was also disagreement about the degree to which teens viewed themselves as requiring additional protection in the workplace and the degree to which organized labour was engaged in the protection of teens. Finally, there was disagreement regarding the utility of using the sexual harassment of female teens as a way to engage allies with significant resources. Some panelists sought to extend analysis of the implications of viewing teens as warranting different treatment. Other panelists sought to expand on the ways that organized labour does and might engage issues of teen employment.

Following revision, a second round of feedback indicated that the Delphi document was broadly accepted. The panelists extended the discussion of internships and work experience programs as well as the degree of teen involvement in unions (where they were organized). The third round of feedback confirmed consensus and is reported below. The fact of using a single panel resulted in some topics on which consensus were elusive. Where full consensus among all seven panelists was not possible, the following typology of consensus was used: "most panelists" means 5 or 6 , "some panelists" means 3 or 4, and "few panelists" means 1 or 2 . The exemplars used below were selected by anonymizing and pooling all exemplars relevant to an issue, with the clearest exemplar selected for inclusion. The uneven distribution of exemplars reflects differing degrees of clarity in the panelists' comments.

\section{Framing Process}

All panelists indicated that cultural stocks around teen employment (which influence what is deemed right and wrong) pose a barrier to the development of sustained and meaningful pressure for increased enforcement. Teen employment is frequently cast as necessary in light of Alberta's alleged labour shortage. Further, adults often view teen employment as character building while its adversities are seen as a rite of passage. 
I think there is this perception, by adults, not so much young people, that work is good for [teens]. And by extension, some people are saying that is how they are going to learn, by actually making mistakes. And if you take that further, you go "getting near misses is the best way to learn." (Panelist 1)

By portraying employment as educational, wage theft and workplace injuries are transformed from violations of workers' rights into opportunities.

I think that just becomes a rationalization of the things that go wrong in workplaces frequented by teenagers as less important. "Oh, you got a burn from a steamer from the espresso machine-well, you learned." It is a way of placing blame on the individual, which is a predisposition anyway. To want to put responsibility for things that happened at work on the worker. "You did it. It is your fault." (Panelist 2)

Most panelists also indicated that compounding the framing of work as positive is the view among many adults that teens are lazy and irresponsible.

We would walk into a restaurant and talk about what we do. "Oh we're teaching kids about their rights in the workplace." And, on more than one occasion, the response is "Teach them their rights? Teach them how to work, first." And that seems to be a pervasive attitude. There is a sense young people are entitled and maybe there is some truth to that, but they shouldn't die because of that. (Panelist 1)

Some panelists noted that Albertans also believe that "good workers don't complain": "This kind of mythology of Albertans as hard, unwavering, uncomplaining workers makes it unlikely that any worker is going to complain." (Panelist 3)

This characterization of "good workers" contains both descriptive (workers don't complain) and prescriptive (workers should not complain) elements. This combination was thought to be powerful because it displaces legitimate concerns regarding illegal and injurious work with an idealized (albeit not ideal) norm which one panelist termed "the cult of git'er done" (Panelist 4).

Some panelists noted that non-compliance with and non-enforcement of employment laws is seen as normal and unproblematic, reflecting the view that the market is self-regulating. Enforcement is also viewed as expensive.

[W] here we have seen the cuts in the last 20 years have been health inspectors, labour law regulation inspectors... [s]o they save the money without watering down the regulations. Watering down the regulations would result in a fight back, but just getting rid of some of the inspectors and enforcement-the ones who don't normally get seen, is a way to save money without getting into the backlash of regulation change. (Panelist 3)

Indeed, enforcement may be viewed as legitimate only when there is some form of "probable cause." 
It is almost like they cut a deal with the employers. "Look, we will set up some explicit rules for when we consider it valid for us to breach your domain." ...It allows them to be almost apologetic for coming in. "We didn't want to come in, but we got this call." (Panelist 2)

It was argued that chronic non-compliance makes non-enforcement the norm among civil servants as well as having a normative effect on the general public and perhaps on teens. In effect, teens are not viewed as "real" workers, but rather as proto-workers with different and lesser workplace rights.

[T]he internship... is the model of youth employment. "You are lucky to get paid at all. You should be paying us for the experience. Don't complain about not getting overtime when you work 10 hours a day. You should be working 12 hours per day and not getting paid at all. Because that is how you learn and show your value and you make contacts." ... I think underlying some of this is... an atmosphere of intimidation and fear and insecurity. [When people] experience declining enforcement of rules and regulation in the labour market... they come to expect it. (Panelist 5)

The notion that teens are not "real" workers may be reinforced by (usually) unremunerated high-school work-experience programs. Some panelists asserted that the notion that teens warrant different rights and treatment reflects a longer and broader trend towards labour-force segmentation by age, gender and race.

This framing of teen employment poses a significant barrier to seeing teen workers' treatment as unjust and as amenable to change. Yet all the panelists noted the idea that young people are vulnerable and require additional protections when operating in the "adult" sphere was a salient and conflicting cultural value. Some panelists suggested that this counter-narrative may only be effective when there is egregious exploitation or the serious injury of a teen worker (see Political Opportunities below). Most panelists indicated that stories were the most effective way of reframing the issue.

Politically, how do you make it relevant? Have more workplace fatalities. That is sad, right? Kill more young people. That is really shitty. ... Maybe it is about humanizing those stories instead of making them statistics that make those "acceptable" losses:

"The number is down this year, so we're doing good." (Panelist 1)

Overall, the panelists indicated that the framing of teenage employment posed significant barriers to the development of pressure on the government to increase its enforcement of teen employment laws.

\section{Political Opportunities}

All panelists indicated that there were relatively few political opportunities for triggering greater state enforcement of teen employment laws. This reflects, in part, a hitherto stable, tight and closed relationship between the (now former) 
Progressive Conservative government and employers. Employer interests were said to be highly organized and engaged in aggressive lobbying. The effectiveness of this employer lobbying stems from the potential or actual political rewards available to politicians who maintain or reduce enforcement (e.g., public support, political donations, post-political career opportunities).

[l]t is a highly exploitable workforce and it is [in] business' — capitalists' -interests to have that pool of labour with minimal government oversight and minimal regulations. ...[W]hy would there be any interest in the government in upsetting the availability of such a useful labour pool? (Panelist 7)

The costs of maintaining or reducing enforcement are low because the lack of enforcement is difficult to see. Any increase to enforcement was thought to be likely to generate political costs (e.g., public criticism, reduction in donations) from employers. Some panelists also suggested that government Members of the Legislative Assembly might be personally uncomfortable with additional enforcement because they view themselves as members of the business class.

How do they explain to their friends that they are just randomly showing up and doing inspections? "What are you doing?" "Why are you targeting me?" And that can be a very touchy political subject for them. (Panelist 3)

By contrast, there is essentially no reward for increasing enforcement and no consequence for maintaining existing levels of enforcement.

[P]arents have quite little oversight of what their children are doing for work and what labour regulations are being violated. So if parents aren't interested in being involved and looking into what is going on, what would be the impetus for government? (Panelist 7)

Panelists disagreed about teens' propensity to seek greater enforcement, either through political action or by using the existing complaint process. Some panelists asserted that the cost to teens of exiting the workplace was lower than the cost of resistance and advocacy. Some other panelists noted that the cost of exit depended on whether the teens' employment was an important contribution to household income or represented a future career path. Accepting illegal or injurious conditions of work may represent a calculation by teens of the likely outcome of resistance. All panelists agreed that the (present) absence of resistance among teens reduces the pressure on the government to increase enforcement. Panelists were unanimous that there could be an opportunity for greater enforcement if the government faced a significant threat to its legitimacy.

I truly hate to say it, but a dead kid. That is an awful, horrible thing to say, but we have seen, time and time again-working alone only became an issue when there were a couple of deaths in BC and Alberta because people were working alone. Issues become a concern only when they become a political problem and they become a political problem, sadly, only when they hit the front page. (Panelist 2) 
A serious injury or death focuses attention on government (in) action and employer practices, thereby changing the political calculus around greater enforcement.

No one wants to see children hurt at work. Especially when it is a case of the rules being insufficient or the rules being broken. Especially if the rules are broken. There is just no sane Albertan of any political stripe [who] is going to look at that and say that is a good thing and that status quo is good enough for young workers. (Panelist 6)

In such circumstances, the panelists believed that the government would place their need for legitimacy above their need for employer support and that employers would be placed on the defensive. Yet the development of a legitimacy crisis around teen injury may be impeded by the lack of data on teen employment complaints or injuries and the private nature of most employment issues. The government can also mitigate threats to its legitimacy via rhetorical strategies such as identifying the event as an unfortunate anomaly or threatening (with or without carrying out) additional and/or targeted educational or enforcement activities until the heat is off.

Overall, the panelists were of the opinion that a legitimacy crisis stemming from the deaths or serious injuries of teen workers was the main potential source of political opportunity around increasing enforcement of teen employment laws. Without such an event, the government's management of pressure through rhetorical strategies or temporary educational or enforcement activities minimizes the political opportunities to trigger greater enforcement. That said, some panelists suggested that mobilizing teens into direct action against specific employers could change employer behaviour and create political opportunities (this idea is more fully developed in Mobilizing Structures below).

\section{Mobilizing Structures}

The panelists had notably less to say about potential mobilizing structures. Some panelists viewed organized labour as unlikely to mobilize teens working in small service-sector workplaces (via traditional organizing techniques).

I can't see any conceivable, practical way that (traditional union organizing) is going to happen in the kinds of industries where these abuses are most common-the food service industry and at the fringes of the service industry in general. Given the nature of their employment, which is quite often temporary in areas where there is not much union presence, and where, frankly, unions haven't figured out a way to function effectively in these high turnover, dispersed workforce situations. (Panelist 5)

While some unions do organize in sectors where a significant number of teens work (e.g., large grocery stores), some panelists noted that these teens were largely disengaged and that there was no concerted engagement effort. 
Some panelists noted the significant and long-term investment by several unions focused on funding rights-based education in the school system and other educational opportunities aimed at young activists. That said, no panelists identified any union-based programs or efforts directly seeking to mobilize young workers outside of traditional organizing efforts.

Some panelists noted that class-conscious activists may be useful allies to teen workers. For example, the Industrial Workers of the World have organized some employer-specific pickets and boycotts targeting "bad employers," yet no panelist asserted that these activities were likely to create a broader mobilizing structure. The panelists were also sceptical about the ability of parents to mobilize. Some panelists indicated that parents tend to solve specific problems affecting their children, rather than addressing systemic issues. Parents may also have a limited capacity to engage in mobilization. Moreover, ineffective enforcement may also discourage resistance, both among parents and teens.

Kids grow up listening to what mom and dad say happened at work. If they listen at all, the kids hear mom and dad saying, "This happened, it was crappy, it was the problem and we couldn't do anything about it." Why would that lesson be lost on the kids? (Panelist 4)

A few panelists recognized the conflicted interests facing many potential allies. No one wants to pay more for food. ...We couch it in terms of what the market will bear, but really what we are saying is that we want that coffee shop to pay its workers "crappily" and, as a result, the only workers they can find are 16-year-olds who are happy working for $\$ 9$ an hour. (Panelist 2)

Most panelists suggested that the transitory nature of teen employment may reduce the willingness of teens to develop a mobilizing structure. Most panelists noted that resistance has both economic and social costs.

[A] young guy came up [and said] "I was really proud, I thought I was doing a really good job and [the employer] came over to my house and... he fired me in front of my parents.... Now my parents think that I am lazy." (Panelist 1)

Teens may also be more vulnerable to employer manipulation.

[A] 12-year-old we met... [who] had been working at a McDonald's... said "Yeah I've been asked to stay late. But my boss, he kind of, like, needs me. I'm the best worker he's got so I'll help him out."

His manager was... asking this 12-year-old to stay, using this... chummy persuasive technique to manipulate him to stay. And not only to stay beyond what employment standards allow, but to manipulate him to work with the deep fryer. 
...Maybe that is not different than any other workplace where the boss tries to manipulate you. But knowing, developmentally, that young people are vulnerable and looking for that kind of reassurance, it is easy to take advantage of that. (Panelist 1)

A part of this vulnerability may stem from teens' experience, in virtually every other situation, that adults look out for their interests. The outward similarities of employers, parents and teachers (i.e., adults giving directions) masks differing motives.

Some panelists suggested that the seemingly endemic nature of the sexual harassment of female teenagers in the workplace may mobilize female teens as well as mothers and allow teens to tap into the expertise and resources of feminist and labour groups. The other panelists questioned whether a gender-specific strategy would obscure the collective and economic experience of "work" and the structural dimensions of employment by emphasizing individual behaviours.

All panelists agreed that teens lack a "place" to discuss workplace issues. A few panelists suggested that social media can be used to organize regionor employer-specific direct-action campaigns regarding teen employment issues that would: 1- cause employers to modify their behaviour; and 2- generate public pressure on the state to enforce teens' employment rights. Social media may also offer a low-cost way for teens and their parents to hear and speak about alternative framings of teen work. However, the public nature of social media may place teens who speak out at risk of termination or of being blacklisted.

\section{Discussion}

This study identified several barriers to generating sustained and meaningful pressure on the government of Alberta to better enforce its laws regulating teen employment. The framing of teen employment as non-problematic marginalizes virtually all claims concerning undesirable, illegal or injurious teen work. The counter-narrative that children warrant additional protection in the workplace contains challenges and tensions. Teens seeking to develop workplace skills and identities may object to being characterized as vulnerable. Employers may also attempt to colonize the assertion that teens warrant special treatment by, for example, redirecting the discussion towards the notion that young workers deserve fewer and different rights (e.g., lower training wages) because teen employment is educational. A second barrier is the significant and stable incentives that politicians have to limit enforcement and the absence of incentives for greater enforcement.

The panelists pointed out that serious injuries or deaths among teen workers could well create a wedge issue between employers and the state, based politicians' need for legitimacy. Highlighting the socially inappropriate nature of 
the serious injury or death of teen workers represents a cultural opportunity that would appear to increase the likelihood of social movement activity (McAdam, 1996). Specifically, fatalities and serious injuries dramatize a glaring contradiction between the widespread view that teens ought to be protected from harm and the deleterious effects of employers' workplace practices and the state's (non-) enforcement activity. A state that allows teens to be harmed via non-enforcement of workplace rights may well be viewed as illegitimate. Drawing the public's attention to such incidents would attach political costs to the state's current level of enforcement and could cause politicians to question the political utility of allowing widespread non-compliance by employers.

Advocates may be able to amplify this (re)framing process by documenting and more broadly communicating teens' perspectives. This may create or strengthen alternative cultural stocks for potential insurgents to draw on, thereby undermining Alberta's blame-the-worker culture, the social approbation around complaining about unsafe and illegal work, and beliefs about the effectiveness of self-regulation in the workplace. That said, Bittle's (2012) and Tucker's (2006) analyses of the Westray amendments to Canada's Criminal Code (following the death of 26 miners) highlight that, while deaths can cause changes in the law, they do not necessarily result in changes to enforcement practices. The destabilizing power of a serious injury or fatality can be mitigated by the state via transient rhetorical, educational or enforcement strategies. Further, highlighting the socially unacceptable nature of such outcomes in order to advocate for policy change comes with the risk that advocates will be accused of trying to exploit the injury or death of a teen.

A third barrier is the absence of a mobilizing structure around teen employment. Unions are not mobilizing teens via traditional organizing efforts and there is no indication that organized labour is interested in organizing workers for purposes other than collective bargaining. The panelists were sceptical that these barriers could be overcome. A few panelists suggested that encouraging teens to visibly complain about poor treatment by employers (e.g., picketing, boycotts, social media campaigns) was a potentially effective way to alter the behaviour of individual employers as well as create political pressure on the state. Demands made outside of complaint resolution and policy development processes may be more difficult for employers and the state to manage. It is unclear whether direct action will trigger a meaningful and enduring reframing of teen employment. There is also the risk to the present and future employment of teens who undertake direct action, especially if such action is organized on social media where employers can view it.

In theory, parents could be powerful and highly motivated actors in demanding better enforcement of the laws regulating teen employment. The literature on 
parental involvement in children's schooling suggests that parental capacity, effort and strategies may vary according to the circumstances and parents' self-efficacy, socioeconomic status and cultural norms (Auerbach, 2007; Deslandes and Bertrand, 2005; Skocpol 1997). A significant barrier to collective parental action (versus an individual parent intervening in a specific issue facing the parent's child) is the absence of an existing parental mobilizing structure that closely "maps" onto teen employment. This absence of a network reflects that teen employment is sporadic, fluid and geographically diffuse. The absence of such a network reduces the opportunities for parents to develop a shared understanding of the regulation of teen employment as problematic and take collective action.

\section{Conclusion}

In this analysis, social movement theory provided a useful structure within which to identify the opportunities and barriers faced by advocates of greater enforcement of teen labour laws in achieving policy change. Focusing attention on the interplay of political opportunities, issues framing and mobilizing structures provided a clear understanding of the options available to insurgents in the short term as well as ways in which this option set could be expanded in the longer term. That said, the small size of the Delphi panel and the absence of employer and government panelists suggest that the results ought to be viewed with caution. Of particular concern is the absence of input from government enforcement staff, which may be able to suggest additional strategies for enhancing enforcement. Further, based on the recent research by Usher et al. (2014), additional analysis of how parents' views of teen employment affect their propensity to take collective action may be warranted.

This study identified significant barriers to the development of sustained and meaningful pressure on the (now former) Progressive Conservative government of Alberta to enforce its laws regulating teen employment. These barriers include a tight business-government relationship that limits the political opportunities available to insurgents seeking change, a framing of violations as a rite of passage and an educational process, and the absence of a mobilizing structure. It also identified opportunities for advocates to press for improved enforcement. These opportunities centre on advocates highlighting the socially unacceptable nature of workplace fatalities and injuries among teen workers as a way to suggest that current workplace and enforcement practices are illegitimate. Reframing teen employment as problematic may destabilize the tight business-government relationship and open up political opportunities to advocate for better enforcement.

The generalizability of this study's specific findings to other jurisdictions is left to the reader. As set out in the literature review, the broad contours of teen 
employment are similar across English-speaking nations, yet there are significant institutional and policy differences among jurisdictions. Recognizing the idiosyncratic nature of each jurisdiction's political economy, this study suggests that it may be useful to use social movement theory as a framework within which to identify opportunities for and barriers to achieving policy changes around the enforcement of employment laws.

\section{References}

Adler, Michael and Erio Ziglio. 1996. Gazing in the Oracle: The Delphi Method and its Application to Social Policy and Public Health. London: Jessica Kingsley.

Alberta. 2011a. Alberta Hansard, April 21, Thomas Lukaszuk, PC. Edmonon: Queen's Printer of Alberta, 810-811.

Alberta. 2011b. Occupational Health and Safety (OHS) Focused Inspection Project: Young Workers. Edmonton: Work Safe Alberta.

Alberta. 2014. Employment Standards Code Consultations. Edmonton: Department of Jobs, Skills, Training and Labour.

Anderson, Danae, Felicity Lamm, Ealing Rasmussen, Peter Shuttleworth and Judith McMorland. 2008. "Child Labour: What is Happening in New Zealand?" Paper presented the 2008 Labour Employment and Work Conference. Wellington, December 11.

Arthurs, Harrry. 2006. Fairness at Work: Federal Labour Standards for the $21^{\text {st }}$ Century. Ottawa: Labour Standards Review Commission.

Auerbach, Susan. 2007. "From Moral Supports to Struggling Advicates: Reconceptualizing Parent Roles in Education Through the Experience of Working-Class Families of Color." Urban Education, 42 (3), 250-283.

Barnetson, Bob. 2009a. "The Regulation of Child and Adolescent Labour in Alberta." Just Labour, 13, 29-47.

Barnetson, Bob. 2009b. "The Regulatory Exclusion of Agricultural Workers in Alberta." Just Labour, 14, 50-74.

Barnetson, Bob. 2010. "Effectiveness of Complaint-Driven Regulations of Child Labour in Alberta." Just Labour, 16, 9-24.

Barnetson, Bob. 2012. "The Validity of Alberta Safety Statistics." Just Labour, 19, 1-21.

Barnetson, Bob. 2013a. "Incidence of Work and Workplace Injury Among Alberta Teens." Just Labour, 20, 14-32.

Barnetson, Bob. 2013b. "Framing and Blaming: Construction of Workplace Injuries by Legislators in Alberta, Canada." International Journal of Occupational and Environmental Health, 19 (4), 332-343.

Barnetson, Bob and Jason Foster. 2012. "Bloody lucky: The Careless Worker Myth in Alberta, Canada." International Journal of Occupational and Environmental Health, 18 (2), 135146.

Bell, Jennifer and Shawn Grushecky. 2006. "Evaluating the Effectiveness of a Logger Safety Training Program." Journal of Safety Research, 37 (1), 53-61. 
Bernstein, Stephanie, Katherine Lippel, Eric Tucker and Leah Vosko. 2006. “Precarious Employment and the Law's Flaws: Identifying Regulatory Failure and Securing Effective Protection for Workers." Precarious Employment: Understanding Labour Market Insecurity in Canada. L. Vosko, ed. Kingston: McGill-Queens University Press, 203-219.

Bittle, Steven. 2012. Still Dying for a Living: Corporate Criminal Liability After the Westry Mine Disaster. Vancouver: University of British Columbia Press.

Blair, Earl, Dong-Chul Seo, Mohammad Torabi and Mark Kaldahi. 2004. "Safety Beliefs and Safe Behavior Among Mid-Western College Students." Journal of Safety Research, 35, 131-140.

Breslin, Curtis, Mieke Koehoorn, Peter Smith and M. Manno. 2003. "Age Related Differences in Work Injuries and Permanent Impairment: A Comparison of Workers' Compensation Claims Among Adolescents, Young Adults, and Adults." Occupational and Environmental Medicine, 60 (9), 10-15.

Breslin, Curtis, Peter Smith, Cam Mustard and Ryan Zhao. 2006. "Young People and Work Injuries: An Examination of Jurisdictional Variation Within Canada." Injury Prevention, 12, 105-110.

Breslin, C., D. Day, E. Tompa, E. Irvin, S. Bhattacharyya, J. Clarke and A. Wang. 2007a. "NonAgricultural Work Injuries Among Youth: A Systematic Review." American Journal of Preventive Medicine, 32 (2), 151-162.

Breslin, Curtis, Peter Smith and James Dunn. 2007b. "An Ecological Study of Regional Variation in Work Injuries Among Young Workers." BMC Public Health, 7: 91.

Breslin, Curtis, Jessica Polzer, Ellen MacEachen, Barbara Morrongiello and Harry Shannon. 2007c. "Workplace Injury or "Part of the Job" ?: Towards a Gendered Understanding of Injuries and Complaints Among Young Workers." Social Science \& Medicine, 64 (4), 782-793.

Breslin, Curtis, Mieke Koehoorn and Donald Cole. 2008. "Employment Patterns and Work Injury Experience Among Canadian 12 to 14 year olds." Canadian Journal of Public Health, 99 (3), 201-204.

Brooks, Daniel, Letitia Davis and Susan Gallagher. 1993. "Work-Related Injuries Among Massachusetts Children: A Study Based on Emergency Department Data." American Journal of Industrial Medicine, 24 (3), 313-324.

Burke, Michael, Sue Sarpy, Kristin Smith-Crowe, Suzanne Chan-Serafin, Rommel Salvador and Gazi Islam. 2005. "Relative Effectiveness of Worker Safety and Health Training Methods." American Journal of Public Health, 96 (21), 315-324.

CARITAS. 2003. Protecting Children at Work: Children's Work Survey. Thorndon: Caritas Aotearoa New Zealand.

Chin, Peter, Christopher DeLuca, Cheryl Poth, Ingrid Chadwick, Nancy Hutchinson and Hugh Munby. 2010. "Enabling Youth to Advocate for Workplace Safety." Safety Science, 48 (5), 570-579.

Clark, Tony. 2013. Personal communication, Researcher for the Alberta Federation of Labour. December 1.

Cohen, Marjorie. 2013. "Teenage Work: Its Precarious and Gendered Nature." Revue Interventions économiques [En ligne], 47 : <http://interventionseconomiques.revues.org/1895> (accessed February 13, 2013)

D’Arcy, Laura, Yasuko Sasai and Sally Stearns. 2011. "Do Assistative Devicies, Training and Workload Affect Injury Incidence? Prevention Efforts by Nursing Homes and Back Injuries Among Nursing Assistants." Journal of Advanced Nursing, 68 (4), 836-845. 
Dal Santo, Janet and Michael Bowling. 2009. "Characteristics of Teens With and Without Work Permits." American Journal of Industrial Medicine, 52, 841-849.

Deslandes, Rollande and Richard Bertrand. 2005. "Motivation of Parent Involvement in Secondary Schooling." Journal of Education Research, 98 (3), 164-176.

Dong, Xuiwen, Pamela Entzel, Yurong Men, Risana Chowdhury and Scott Schneider. 2004. "Effects of Safety and Health Training on Work-Related Injury Among Construction Laborers." Journal of Occupational and Environmental Science, 46 (12), 1222-1228.

Dorman, Peter. 2001. Child Labour in the Developed Economies. Geneva: International Labour Office.

Dufort, Vincent, Jonathan Kotch, Stephen Marshall, Anna Waller and John Langley. 1997. "Occupational Injuries Among Adolescents in Dunedin, New Zealand, 1990-1993." Annals of Emergency Medicine, 30 (3), 266-273.

Dunn, Kathleen, Carol Runyan, Lisa Cohen and Michael Schulman. 1998. "Teens at Work: A Statewide Study of Jobs, Hazards, and Injuries." Journal of Adolescent Health, 22 (1), 19-25.

Evensen, Christian, Michael Schulman, Carol Runyan, Ronda Zakocs and Kathleen Dunn. 2000. "The Downside of Adolescent Employment: Hazards and Injuries Among Working Teens in North Carolina." Journal of Adolescence, 23 (5), 545-560.

Foster, Jason. 2011. "Talking Ourselves to Death? The Prospects for Social Sialogue in North America-Lessons from Alberta." Labor Studies Journal, 36 (2), 288-306.

Gamson, William and David Meyer. 1996. "Framing Political Opportunity." Comparative Perspectives on Social Movements. D. McAdam, J. McCarthy and M. Zaid, eds. New York: Cambridge University Press, 275-290.

IPEC. 2008. Hazardous Child Labour. Geneva: International Programme on the Elimination of Child Labour.

Jenkins, Craig and Charles Perrow. 1977. "Insurgency of the Powerless: Farm Worker Movements (1946-1973)." American Sociological Review, 42 (2), 249-268.

Kinn, Steven, Sadik Khuder, Michael Biscesi and Sandra Woolley. 2000. "Evaluation of Safety Orientation and Training Programs for Reducing Injuries in the Plumbing and Pipefitting Industry." Journal of Occupational and Environmental Medicine, 42 (12), 1142-1147.

Koehoorn, Mieke, Curtis Breslin and Fan Xu. 2008. "Investigating the Longer-Term Health Consequences of Work-Related Injuries Among Youth." Journal of Adolescent Health, 43 (5), 466-473.

Kriesi, Hanspeter 1995. "Political Opportunity Structure of New Social Movements: Its Impact on Their Mobilization." The Politics of Social Protest: Comparative Perspectives on States and Social Movements. J. Jenkins and B. Klandermas, eds. London: University of Minnesota Press, 167-198.

Kruse, Douglas and Douglas Mahony. 2000. "Illegal Child Labor in the United States: Prevalence and Characteristics." Industrial \& Labor Relations Review, 54 (1), 17-40.

Levine, Marvin. 2003. Children for Hire: The Perils of Child Labor in the United States. Westport: Praeger.

Laberge, Marie, Ellen MacEachen and Benedicte Calvet. 2014. "Why Are Occupational Health and Safety Training Approaches Not Effective? Understand Young Worker Learning Processes Using an Ergonomic Lens." Safety Science, 68, 250-257. 
Lewchuck, Wayne, Marlea Clarke and Alice de Wolff. 2011. Working Without Commitments: The Health Effects of Precarious Employment. Montreal: McGill-Queen's University Press.

Lewchuk, Wayne, Alice de Wolff, Andy King and Michael Polanyi. 2006. "The Hidden Costs of Precarious Employment: Health and the Employment Relationship." Precarious Employment: Understanding Labour Market Insecurity in Canada. L. Vosko, ed. Montreal: McGill-Queen's University Press, 141-162.

Lewko, John, Carol Runyan, Cindy-Lynne Tremblay, John Staley and Richard Volpe. 2010. "Workplace Experiences of Young Workers in Ontario." Canadian Journal of Public Health, 101 (5), 380-384

McAdam, Doug. 1996. "Conceptual Origins, Current Problems and Future Directions." Comparative Perspectives on Social Movements. D. McAdam, J. McCarthy and M. Zald, eds. New York: Cambridge University Press, 23-40.

McAdam, Doug, John McCarthy and Mayer Zald. 1996. "Introduction: Opportunities, Mobilizing Structures, and Framing Processes-Towards a Synthetic, Comparative Perspective on Social Movements." Comparative Perspectives on Social Movements. D. McAdam, J. McCarthy and M. Zald, eds. New York: Cambridge University Press, 1-21.

McCall, Brian, Irwin Horwitz and B. Carr. 2007. "Adolescent Occupational Injuries and Workplace Risks: An Analysis of Oregon Workers' Compensation Data 1990-1997." Journal of Adolescent Health, 41 (3), 248-255.

McCarthy, John. 1996. "Constraints and Opportunities in Adopting, Adapting and Inventing." Comparative Perspectives on Social Movements. D. McAdam, J. McCarthy and M. Zald, eds. New York: Cambridge University Press, 141-151.

Mortimer, Jeylan. 2003. Working and Growing up in America. Cambridge: Harvard University Press.

Okoli, Chitu and Suzanne Pawlowski. 2004. "The Delphi Method as a Research Tool: An Example, Design Considerations and Applications." Information \& Management, 42: 15-29.

Ontario. 2004. Annual Report of the Auditor General. Toronto, Auditor General.

Parker, David, William Carl, Ronald French and Frank Martin. 1994a. "Characteristics of Adolescent Work Injuries Reported to the Minnesota Department of Labor and Industry." American Journal of Public Health, 84, 606-611.

Parker, David, William Carl, Ronald French and Frank Martin. 1994b. "Nature and Incidence of Self-Reported Adolescent Work Injury in Minnesota." American Journal of Industrial Medicine, 26, 529-541.

Pickett, William, Lisa Hartling, Robert Brison and Judith Guernsey. 1999. "Fatal Work-Related Farm Injuries in Canada, 1991-1995." Canadian Medical Association Journal, 160 (130), 1843-1848.

Pisaniello, Dino, Sasha Stewart, Nasreen Jahan, Ssandra Pisaniello, Helen Winefield and Annette Braunack-Mayer. 2013. "The Role of High Schools in Introductory Occupational Safety Education - Teacher Perspectives on Effectiveness." Safety Science, 55, 53-61.

Power, Nicole and Sumaiya Baqee. 2010. "Constructing a 'culture of safety': An examination of the assumptions embedded in occupational safety and health curricula delivered to high school students and fish harvesters in Newfoundland and Labrador, Canada." Policy and Practice in Health and Safety, 8 (1), 5-23. 
Probst, Tahira, Claudio Barbaranellu and Laura Petitta. 2013. "The Relationship Between Job Insecurity and Accident Under-Reporting: A Test in Two Countries." Work \& Stress, 27 (4), 383-402.

Quinlan, Michael. 1999. "The Implication of Labour Market Restructuring in Industrialized Societies for Occupational Health and Safety." Economic and Industrial Democracy, 20, 427-460.

Quinlan, Michael and Claire Mayhew. 1999. "Precarious Employment and Workers' Compensation." International Journal of Law and Psychiatry, 22 (5-6), 491-520.

Quinlan, Michael, Claire Mayhew and Philip Bohle. 2001. "The Global Expansion of Precarious Employment, Work Disorganization and Consequences for Occupational Health: A Review of Recent Research." International Journal of Health Services, 31 (2), 335-414.

Rauscher, Kimbely, Carol Runyan, Michael Schulman and Michael Bowling. 2008. "US Child Labor Violations in the Retail and Service Industries: Findings from a National Survey of Working Adolescents." American Journal of Public Health, 98 (9), 1693-1699.

Raykov, Milosh and Alison Taylor. 2013. "Health and Safety for Canadian Youth in Trades." Just Labour, 20, 33-50.

Runyan, Carol, Michael Schulman, Janet Dal Santo, Michael Bowling and Robert Agans. 2009. "Attitudes and Beliefs about Adolescent Work and Workplace Safety Among Parents of Working Adolescents." Journal of Adolescent Health, 44 (4), 349-355.

Runyan, Carol, Catherine Vladutiu, Michael Schulman and Kimberly Rauscher. 2011. "Parental Involvement with Their Working Teens." Journal of Adolescent Health, 49 (1), 84-86.

Runyan, Carol, Michael Schulman and Lawrence Scholl. 2012. "Adolescent Employment and Injury in the United States." Injury Prevention for Children and Adolescents: Research, Practice, and Advocacy, $2^{\text {nd }} E d$. K. DeSafey Liller, ed. Washington: American Public Health association, 189-214.

Staff, Jeremy, Emily Messersmith and John Schulenberg. 2009. "Adolescents and the World of Work." Handbook of Adolescent Psychology, $3^{\text {rd }}$ Ed. R. Lerner and L. Steinberg, eds. New York: Wiley, 270-313.

Shearn, Peter. 2006. "Teaching Practice in Safety Education: Qualitative Evidence." Research Papers in Education, 21, 335-359.

Schultz, Lynne and Alison Taylor. 2006. "Children at Work in Alberta." Canadian Public Policy, 32 (4), 431-441.

Skocpol, Theda. 2002. "What Will it Take to Build a Family-Friendly America." Taking Parenting Public: The Case for a New Social Movement. S. Hewlett, N. Rankin and C. West, eds. Lanham: Rowman and Littlefield, 219-233.

Skulmoski, Gregory, Francis Hartman and Jennifer Krahn. 2007. "The Delphi Method for Graduate Research." Journal of Information Technology Education, 6, 1-21.

Smith, Peter and Cam Mustard. 2007. "How Many Employees Receive Safety Training During Their First Year of a New Job?" Injury Prevention, 13, 37-41.

Thomas, Mark. 2009. Regulating Flexibility: The Political Economy of Employment Standards. Montreal: McGill-Queen's University Press.

Tompa, Emile, Scott Treithick and Chris McLeod. 2007. "Systematic Review of the Prevention Incentives of Insurance and Regulatory Mechanisms for Occupational Health and Safety." Scandinavian Journal of Work, Environment and Health, 33 (2), 85-95. 
Tucker, Eric. 2006. "Accountability and Reform in the Aftermath of the Westray Mine Explosion." Working Disasters: The Politics of Recognition and Response, E. Tucker, ed. Amityville: Baywood Publishing, 277-309.

Tucker, Sean, Dayle Diekrager, Nick Turner and Kevin Kelloway. 2014. "Work-Related Injury Underreporting Among Young Workers: Prevalence, Gender Differences, and Explanations for Underreporting." Journal of Safety Research. DOI 10.1016/j/jsr.2014.04.001.

Tucker, Sean and Nick Turner. 2013. "Waiting for Safety: Responses by Young Canadian Workers to Unsafe Work." Journal of Safety Research, 45, 103-110.

Tucker, Sean and Nick Turner. 2014. "Safety Voice Among Young Workers Facing Dangerous Work: A Policy-Capturing Approach." Safety Science, 62, 530-537.

Tullar, Jessica, Shelley Brewer, Benjamin Amick, Emma Irvin, Quenby Mahood, Lisa Pompeii, Anna Wang, Dwayne Van Eerd, David Gimeno and Bradley Evanoff. 2010. "Occupational Safety and Health Interventions to Reduce Musculoskeletal Symptoms in the Health Care Sector." Journal of Occupational Rehabilitation, 20(2), 199-219.

Usher, Amelia, Curtis Breslin, Ellen MacEachen, Mieke Koehoon, Marie Laberge, Luc Laberge, Elise Ledoux and Imelda Wong. 2014. "Employment and Work Safety Among 12 to 14 Year Olds: Listening to Parents." BMC Public Health, 14: 1021-1031.

Vosko, Leah. 2006. "Precarious Employment: Towards and Improved Understanding Labour Market Insecurity." Precarious Employment: Understanding Labour Market Insecurity in Canada, L. Vosko, ed. Montreal: McGill-Queen's University Press, 3-42.

Waehrer, Geetha and Ted Miller. 2009. "Does Safety Training Reduce Work Injury in the United States?" The Ergonomics Open Journal, 2, 26-39.

Weil, David 2012. "'Broken windows,' vulnerable workers and the future of worker representation. The Forum: Labour in American Politics, 10 (1), Article 9.

Weil, David and Amanda Pyles. 2005. "Why Complain? Complaints, Compliance and the Problem of Enforcement in the US Workplace." Comparative Labor Law \& Policy Journal, 27 (1), 59-92.

Zald, Mayer. 1996. "Culture, Ideology, and Strategic Framing." Comparative Perspectives on Social Movements. D. McAdam, J. McCarthy and M. Zald, ed. New York: Cambridge University Press, 261-274.

Zierold, Kristina and H. Anderson. 2006a. "The Relationship Between Work Permits, Injury, and Safety Training Among Working Teenagers." American Journal of Industrial Medicine, 49 (5), 360-366.

Zierold, Kristina, S. Garman and H. Anderson. 2004. "Summer Work and Injury Among Middle School Students, Aged 10 to 14 Years." Occupational and Environmental Medicine. 61, 518-522. 


\section{SUMMARY}

\section{The Prospects for Greater Enforcement of Teen Employment Laws in Alberta, Canada. 'Politically, how do you make it relevant?... Kill more young people!'}

This study uses a Delphi analysis to identify significant barriers to the development of sustained and meaningful pressure on the Alberta government to increase the enforcement of its laws regulating the employment of teenagers. In addition to general employment laws (e.g., wage payment, occupational health and safety) that appear to go broadly unenforced, Alberta also appears not to enforce laws specifying the hours during which teens may work, the occupations in which they may work and the job tasks they may perform. The result is wage theft, workplace injury and illegal forms of employment among teens. The seven Delphi panelists-a mixture of academics, trade unionists and staff members in not-for-profit agencies with an interest in employment matters-identify a tight business-government relationship as an important limit on the political opportunities available to insurgents seeking change. Insurgents must also grapple with a framing that minimizes concerns around teen employment, i.e. by framing illegal or injurious work as an educational rite of passage and complaints as whining. Together, these barriers significantly limit the opportunities to pressure the state to enhance enforcement.

Panelists also noted that there is no mobilizing structure in place that teenage workers and their allies can access. Alberta's labour movement has had limited success organizing the service sector (where most teens are employed). Some panelists suggested leveraging the widespread sexual harassment of female teen workers as a way to access existing networks and resources in feminist and labour organizations. Other panelists argued that focusing on sexual harassment would emphasize individual employers' misbehaviour and obscure the class-based nature of inadequate enforcement.

Most panelists suggested that highlighting the socially inappropriate nature of the death or serious injury of teen workers would be the best way to destabilize the existing barriers to better enforcement of employment laws. The opportunity to do so is (fortunately) rare and may be difficult to leverage. Indeed, research on high profile occupational fatalities in Canada (e.g., the Westray Mine disaster) suggests that such fatalities do not have a significant effect on state enforcement efforts. In the meantime, advocates such as organized labour and community groups may also work to alter conventional views of teen employment by supporting educational or artistic endeavours that problematize teen employment. This could include identifying the risks and consequences of the non-enforcement of laws regulating the employment of teens (such as injury and wage theft) as well as highlighting the reasons why teen workers warrant the enforcement of their workplace rights by the state.

KEYWORDS: Teen, employment, injury, social movement theory, Delphi. 


\section{RÉSUMÉ}

\section{Les perspectives d'un renforcement des lois relatives au} travail des jeunes en Alberta, Canada. « Comment rendre cela pertinent politiquement? [...] en tuant davantage de jeunes! »

La présente étude a recours à une analyse de type Delphi afin d'identifier les principales barrières au développement de pressions soutenues et sérieuses sur le gouvernement albertain pour qu'il améliore ses lois relatives à l'emploi des jeunes. Actuellement, outre des lois générales en matière d'emploi (par exemple, sur les salaires, la santé et sécurité au travail) - lois qui semblent peu appliquées -, l'Alberta apparaît également peu encline à renforcer ses lois déterminant le nombre d'heures durant lesquels les jeunes peuvent travailler, tout comme les tâches qu'ils peuvent accomplir. Le résultat en est un de " vol » salarial, d'accidents de travail et de formes illégales d'emploi pour les jeunes. Les sept participants au panel Delphi - des représentants provenant du monde académique, du milieu syndical et d'agences à but non lucratif, ayant tous un intérêt pour les questions d'emploi des jeunes -, identifient la relation serrée entre milieux d'affaires et gouvernement comme étant la limite principale aux possibilités politiques de changements. Les réformateurs font également face à un ensemble de préjugés qui minimisent les préoccupations envers le travail des jeunes, préjugés s'appuyant sur l'idée qu'un environnement illégal ou dangereux au travail constitue une sorte de passage initiatique à l'âge adulte. Ensemble, ces barrières limitent significativement les possibilités de faire pression sur l'État afin qu'il légifère pour améliorer la situation.

Les participants ont également noté l'absence de structures de mobilisation auxquelles pourraient avoir accès les jeunes travailleurs et leurs alliés. Le mouvement syndical albertain a, de plus, connu un succès limité dans ses tentatives d'organisation du secteur des services (là où la majorité des jeunes travaillent). Certains participants pensent que la lutte contre les abus sexuels généralisés à l'égard des jeunes travailleuses permettrait d'accéder aux réseaux et à des ressources existantes dans le mouvement féministe et dans les organisations syndicales. D'autres, par contre, sont d'avis que mettre l'emphase sur la lutte contre les abus sexuels ne ferait que cibler les comportements déviants d'employeurs individuels et obscurcirait le fait que la volonté de ne pas renforcer les lois repose sur des intérêts de classe.

La plupart des participants proposent de souligner le caractère socialement inapproprié des blessures sérieuses, voire même de décès, de jeunes travailleurs, ce qui pourrait constituer un moyen important d'ébranler les barrières actuelles à l'égard du renforcement de ces lois. De telles occasions sont plutôt rares et il peut être difficile de capitaliser sur celles-ci. Hors de tout doute, la recherche au Canada sur les professions à haut risque d'accidents mortels démontre que les tragédies (par exemple, le désastre de la Mine Westray) ont peu d'effet significatif sur les efforts des États à renforcer l'application des lois en la matière. Entre-temps, les partisans de réformes, comme les membres d'organisations syndicales et de groupes communautaires, peuvent œuvrer à modifier la perception conventionnelle à l'égard 
de l'emploi des jeunes, tout en supportant les efforts provenant des milieux artistiques et de l'éducation qui se préoccupent des conditions de travail des jeunes. Leur analyse pourrait également inclure l'identification des risques et des conséquences de ne pas appliquer les lois régulant le travail des jeunes (comme les blessures et le « vol » salarial), de même que l'élaboration des raisons qui militent en faveur d'un renforcement par l'État des droits des jeunes en milieu de travail.

MOTS-CLÉS : Jeunes, emploi, lésions, théorie du mouvement social, Delphi.

\section{RESUMEN}

\section{Las perspectivas de una mejor aplicación de la ley sobre el empleo de adolescentes en Alberta, Canadá. 'Políticamente, cómo hacer esto sea adecuado? ... Matar gente tan joven'.}

Este estudio utiliza un análisis Delphi para identificar barreras significativas al desarrollo de una presión sustentada y esclarecida sobre el gobierno de Alberta para aumentar el poder coercitivo de las leyes que regulan el empleo de adolescentes. Además de las leyes generales del empleo (pago de sueldos, salud y seguridad ocupacional) que parecen, en general, en perdida de ejecución, Alberta parece también no hacer respetar las leyes que especifican las horas y las ocupaciones aplicables al trabajo de adolescentes así como el tipo de trabajo que ellos pueden efectuar. El resultado es un robo de sueldos de adolescentes, numerosas heridas en el lugar de trabajo y formas de empleo ilegales. Los siete panelistas de Delphi - compuesto de académicos, sindicalistas y miembros de agencias con fines no lucrativas interesados en los problemas del empleo - identifican la estrecha relación entre el gobierno y las empresas como un límite importante a las oportunidades disponibles para aquellos que buscan un cambio. Los militantes deben también luchar contra el estratagema que minimiza los problemas en torno al empleo de adolescentes, el estratagema que considera el trabajo ilegal o arriesgado como un rito de pasaje, y aquellos que se quejan como llorones. En su conjunto, estas barreras limitan significativamente las oportunidades de presión sobre el estado para mejorar la aplicación de la ley.

Los panelistas notaron también que no hay estructura de movilización a la cual puedan tener acceso los adolescentes trabajadores y sus aliados. El movimiento laboral de Alberta ha tenido éxito limitado en la organización del sector servicios (que emplea la mayoría de adolescentes). Algunos panelistas sugieren utilizar como palanca el casi-generalizado acoso sexual de trabajadoras adolescentes como un medio de acceso a las redes y recursos existentes de las organizaciones laborales y feministas. Otros panelistas piensan que focalizar en el acoso sexual podría focalizar el mal comportamiento individual de los empleadores ocultando la naturaleza de clase de la aplicación inadecuada de la ley. La mayoría de panelistas sugieren que el deceso o las lesiones graves de adolescentes trabajadores (tan tristes que pueden ser) podrían ofrecer oportunidades importantes para desestabilizar las barreras existentes para el reforzamiento adicional de las leyes sobre el empleo. 
Tales oportunidades son (afortunadamente) raras y puede ser difícil de capitalizar sobre ellas. La investigación sobre las muertes de alto perfil en el trabajo en Canadá (por ejemplo, el desastre de la Mina Westray) sugiere que éstas no tienen un efecto significativo en los esfuerzos de aplicación del estado. Mientras tanto, los defensores como los grupos laborales y comunitarios organizados también pueden trabajar para modificar la visión convencional del empleo adolescente apoyando los esfuerzos educativos o artísticos que cuestionan el empleo juvenil. Esto puede incluir la identificación de riesgos y consecuencias del incumplimiento de las leyes que regulan el empleo adolescente (tales como las lesiones y el robo de sueldos) y la explicación de las razones por las cuales el estado debería asegurar el respeto de los derechos de los trabajadores adolescentes en el lugar de trabajo.

PALABRAS CLAVES: Adolescentes, empleo, lesiones, teoría de movimiento social, Delphi. 